\title{
ANALISIS MULTILAYER VARIABILITAS UPWELLING DI PERAIRAN SELATAN JAWA
}

\section{MULTILAYER ANALYSIS OF UPWELLING VARIABILITY IN SOUTH JAVA SEA}

\author{
Bambang Sukresno $^{1}$, Denarika Jatisworo ${ }^{1}$ dan Denny Wijaya Kusuma ${ }^{1}$ \\ ${ }^{1}$ Balai Riset dan Observasi Laut, Kementerian Kelautan dan Perikanan \\ Desa Perancak, Jembrana, Bali, Telp 0365.44266, Fax 0365.44278 \\ E-mail : bambang_sukresno@yahoo.com \\ Diterima : 6 Februari 2018 ; Diterima setelah perbaikan: 26 Maret 2018 ; Disetujui tanggal: 27 Maret 2018 \\ DOI: http://dx.doi.org/10.15578/jkn.v1i1.6619
}

\begin{abstract}
ABSTRAK
Variabilitas upwelling di perairan selatan Jawa telah diidentifikasi. Analisis multilayer dilakukan dengan menggunakan data ARGO Float periode 2016 hingga 2017. Variabilitas suhu permukaan laut (SPL) dan klorofil-a (klor-a) dianalisis dengan menggunakan data satelit MODIS Aqua periode 2007 hingga 2017. Pengaruh El Nino Southern Oscillation (ENSO) terhadap upwelling dilakukan dengan menggunakan indeks Oceanic Nino Index (ONI), sedangkan pengaruh Indian Ocean Dipole (IOD) direpresentasikan dengan menggunakan indeks Dipole Mode Index (DMI). Dari hasil penelitian diketahui bahwa ENSO mempengaruhi intensitas upwelling. Pada periode el nino intensitasnya mengalami peningkatan yang diikuti oleh penurunan SPL dan naiknya konsentrasi klor-a, sebaliknya pada periode la nina terjadi penurunan intensitas yang diikuti naiknya SPL dan turunnya konsentrasi klor-a. Peningkatan intensitas juga terdeteksi pada saat terjadi periode IOD positif, sedangkan penurunan intensitas terjadi pada periode IOD negatif.
\end{abstract}

Kata kunci: Analisis multilayer, Upwelling, Laut Selatan jawa, ARGO Float, Suhu Permukaan Laut, Klorofil-a.

\begin{abstract}
Upwelling variability in the Indian Ocean South of Java has been identified. Multilayer analysis was performed using ARGO Float data during 2016 - 2017. Variability of sea surface temperature (SST) and chlorophyll-a concentration (chlor-a) were analyzed using Aqua MODIS satellite data during 2007 - 2017. The influence of El Nino Southern Oscillation (ENSO) on upwelling intensity was conducted using the Oceanic Nino Index (ONI), while the influence of Indian Ocean Dipole (IOD) was represented by using Dipole Mode Index (DMI). Result of the study show that ENSO give high impact on upwelling variability. During el nino period, the intensity has increased, followed by a decrease in SPL and increased in chlor-a concentration, on the other hand during la nina period there is a decrease of intensity followed by an increase in SPL and a decrease in chlor-a concentration. Increased intensity was also detected during a positive IOD period, while decreased intensity was occurred during a negative IOD period.
\end{abstract}

Keywords: Multilayer Analysis, Upwelling, South Java Sea, ARGO Float, Sea Surface Temperature, Chlorophyl-a 


\section{PENDAHULUAN}

Perairan selatan Jawa memiliki karakteristik yang unik karena adanya berbagai faktor oseanografi, salah satu fenomena oseanografi tersebut adalah adanya upwelling yang merupakan respon terhadap arah dan kecepatan angin yang berasosiasi dengan sistem iklim musim (Sprintall et al., 1999). Fenomena Oseanografis tersebut sering diasosiasikan dengan penurunan tinggi permukaan laut dan suhu permukaan laut (SPL). Disisi lain juga dicirikan dengan naiknya massa air laut dari lapisan bawah ke permukaan dengan temperatur yang lebih dingin dan kandungan nutrien yang lebih banyak. Pada musim timur antara bulan Juni hingga Oktober terjadi pergeseran pusat upwelling ke arah barat mendekati Sumatra hingga ke ekuator. Seiring dengan perubahan musim, pada musim barat antara bulan November hingga bulan Maret terjadi penurunan intensitas. Analisis variabilitas intensitas di selatan Jawa dilakukan dengan menggunakan data timeseries SPL dan konsentrasi klorofil-a (Klor-a) yang diperoleh dari data satelit (Susanto et al., 2001). Pada musim timur (bulan Juni hingga Oktober) intensitas upwelling mengalami peningkatan sehingga menyebabkan SPL lebih dingin dan serta Klor-a lebih tinggi dibandingkan pada musim barat (Ningsih et al., 2013; Siswanto \& Suratno, 2008; Kunarso et al., 2012).

Dengan menggunakan analisis data satelit Susanto \& Marra (2005), menemukan bahwa peningkatan konsentrasi Klor-a di selatan Jawa pada Musim Timur (MT) menyebar ke arah selatan lebih dari $2^{\circ}$ astronomis atau lebih dari $220 \mathrm{~km}$. Dengan menggunakan indeks Nino 3,4 sebagai representasi El Nino Southern Oscillation (ENSO) dan Indeks Indian Ocean Dipole (IOD), maka pengaruh ENSO dan IOD di selatan Jawa dapat diketahui. Iskandar et al. (2009) juga menyatakan bahwa IOD memberikan pengaruh terhadap konsentrasi klor-a di selatan Jawa. Struktur vertikal upwelling bisa dianalisis dengan menggunakan data temperatur di beberapa kedalaman. Salah satu korelasi antara upwelling dengan konsentrasi klor-a adalah melalui mekanisme naiknya nitrat dari kedalaman sekitar 100 $\mathrm{m}$ ke permukaan yang memberikan suplai nutrien sehingga terjadi kelimpahan klor-a (Xing et al., 2012). Secara umum upwelling bisa diidentifikasi dengan adanya trend penurunan temperatur pada kolom air dari permukaan hingga kedalaman tertentu. Tren penurunan temperatur di selatan Jawa pada periode Juli hingga Oktober terlihat jelas dari permukaan hingga kedalaman $100 \mathrm{~m}$. Kemudian dari kedalaman $100 \mathrm{~m}$ hingga kedalaman $200 \mathrm{~m}$ trend penurunan temperatur tersebut semakin kecil dan kemudian di kedalaman dibawah $200 \mathrm{~m}$ trend penurunan temperatur sudah tidak terlihat lagi (Varela et al., 2016).

Wilayah Indonesia mempengaruhi iklim global (Ilahude \& Nontji, 1999). Variabilitas SPL di Indonesia akan mempengaruhi distribusi konveksi dan presipitasi (Aldrian \& Susanto, 2003). Variabilitas musiman SPL di wilayah Indonesia bisa mencapai $4{ }^{\circ} \mathrm{C}$ dimana jauh lebih tinggi dibandingkan variabilitas SPL di samudera Pasifik bagian barat maupun Samudera Hindia bagian timur yang hanya berkisar $1,5^{\circ} \mathrm{C}$. Sementara itu variabilitas tahunan SPL dengan intensitas mencapai lebih dari $4{ }^{\circ} \mathrm{C}$ didapati di perairan selatan Jawa hingga Sumatera. Perubahan SPL sebesar $1{ }^{\circ} \mathrm{C}$ di wilayah Indonesia akan mempengaruhi perubahan presipitasi di seluruh wilayah Indo-Pasifik (Qu et al., 2005).

Variabilitas antar tahunan intensitas upwelling terdeteksi dengan menganalisis data SPL dan Klor-a dalam rentang waktu yang cukup panjang sehinga terlihat adanya anomali pada periode tertentu. Berdasarkan pada penelitian terdahulu, dapat diketahui bahwa salah satu faktor yang mempengaruhi anomali tersebut adalah ENSO melalui suatu aliran masa air yang mengalir dari Samudera Pasifik menuju samudera Hindia melewati perairan Indonesia yang disebut sebagai Indonesian Through Flow (ITF) atau Arus Lintas Indonesia (ARLINDO). Intensitas arus ITF ini mengalami fluktuasi seiring dengan perubahan indeks ENSO, dimana pada periode el nino massa air yang mengalir dari samudera Pasifik ke Samudera Hindia mengalami peningkatan volume sehingga mempengaruhi temperatur di Samudera Hindia khususnya di selatan Jawa, sebaliknya pada periode la nina volumenya mengalami penurunan (Susanto et al., 2001). Upwelling di selatan Jawa mengalami variabilitas musiman seiring dengan perubahan arah dan kecepatan angin. Namun demikian di bagian selatan Jawa Timur relatif stabil sepanjang tahun. Hal ini dipengaruhi oleh adanya masa air dari Samudera Pasifik yang masuk ke Samudera Hindia dengan mekanisme ITF melalui selat Lombok, selat Ombai dan celah Timor (Kuswardani \& Qiao, 2014). Pengaruh ITF dapat diidentifikasi melalui analisis menggunakan Ocean General Circulation Model (OGCM), dari analisis tersebut diketahui bahwa massa air ITF yang keluar melalui Selat lombok terdistribusi ke wilayah selatan Jawa dan naik ke permukaan melalui mekanisme upwelling (Valsala \& Maksyutov, 2011).

Pada periode el nino, upwelling di selatan Jawa mengalami peningkatan intensitas sehingga SPL lebih dingin dan Klor-a lebih tinggi dibandingkan pada tahun 
tahun normal, sebaliknya pada periode la nina, SPL lebih hangat dan Klor-a lebih rendah dibandingkan pada tahun tahun normal. Selain ENSO, upwelling di selatan Jawa juga dipengaruhi oleh IOD, dimana pada periode IOD positif SPL lebih dingin dan Klor-a lebih tinggi dibandingkan pada tahun tahun normal, sebaliknya pada periode IOD negatif SPL lebih hangat dan Klor-a lebih rendah dibandingkan pada tahun tahun normal (Ningsih et al., 2013 dan Du et al., 2008). Lebih khusus Rahul et al. (2008), meneliti kaitan antara IOD dengan SPL dan Klor-a di selatan Jawa hingga barat Sumatera pada periode IOD positif tahun 1997 dan menyatakan bahwa pada tahun tersebut SPL mengalami penurunan/lebih dingin dari kondisi normal hingga $4^{\circ} \mathrm{C}$ yang di ikuti dengan peningkatan konsentrasi Klor-a.

Kunarso et al. (2005), menyatakan bahwa lokasi upwelling merupakan daerah yang potensial untuk penangkapan ikan tuna karena memiliki konsentrasi plankton yang tinggi yang menyebabkan berkumpulnya ikan-ikan kecil sebagai makanan ikan tuna. Selain itu juga daerah tersebut memiliki temperatur yang sesuai dengan kehidupan ikan tuna. Amri et al. (2015), menganalisis pengaruh ENSO dan IOD terhadap produksi penangkapan ikan tuna sirip kuning (Thunnus albacares). Analisis dilakukan dengan menggunakan data SPL dan Klor-a yang diperoleh dari data satelit MODIS-Aqua. Dari hasil penelitian tersebut diketahui bahwa ENSO dan IOD mempengaruhi intensitas upwelling di selatan Jawa yang kemudian mempengaruhi produktifitas primer sebagai indikator daerah potensial untuk penangkapan ikan tuna sirip kuning. Pengaruh ENSO dan IOD terhadap produksi penangkapan ikan lemuru (Sardinella lemuru) dan ikan tuna sebelumnya telah diteliti oleh Gaol et al. (2002), dimana dari hasil penelitian diketahui bahwa ENSO dan IOD mempengaruhi SPL dan klor-a. Kelimpahan ikan lemuru berasosiasi dengan kelimpahan klor-a sebagai sumber makanannya. Hal yang sama juga dinyatakan oleh Pranowo et al. (2016), yang meneliti intensitas upwelling dengan kelimpahan ikan tuna melalui analisis data Mixed Layer Depth (MLD).

Meyers et al. (2007), menjelaskan bahwa IOD merupakan mode variabilitas SPL dan subsurface temperature dalam skala basin di Samudera Hindia. Pada beberapa kejadian, periode IOD positif terjadi bersamaan dengan periode el nino, begitu juga periode IOD negatif terjadi bersamaan dengan periode la nina. Namun demikian klasifikasi ENSO dan IOD sebagai sebuah fenomena yang saling independen dapat dilakukan. Salah satu dasar penentuan klasifikasi ENSO adalah dengan menggunakan analisis terhadap upwelling di Samudera Pasifik bagian barat, sedangkan klasifikasi IOD dilakukan dengan analisis upwelling di selatan Jawa. Disisi lain Wardani et al. (2014), dengan menggunakan data ARGO Float pada periode tahun 2004 hingga tahun 2010 menemukan bahwa ENSO dan IOD mempengaruhi salinitas di perairan selatan Jawa hingga selatan Nusa Tenggara.

Penggunaan data timeseries SPL dan klor-a untuk identifikasi upwelling di selatan Jawa dapat dilakukan salah satunya dengan menggunakan data satelit Aqua/ Terra MODIS. Sensor MODIS (Moderate Resolution Imaging Spectroradiometer) merupakan salah satu instrumen yang dikembangkan oleh National Aeronautics and Space Administration (NASA) pada program Earth Observing System (EOS). MODIS dibawa oleh wahana satelit Aqua dan satelit Terra yang memindai permukaan bumi pada orbit polar near sun syncronous (Barnes et al., 2003). Untuk aplikasi kelautan, MODIS memiliki 36 produk ocean color termasuk konsentrasi klor-a serta 4 produk SPL (Savtchenko et al., 2004). Data SPL dari sensor MODIS diproduksi berdasarkan algoritma MODIS Infrared Sea Surface Temperature Algorithm ATBD version 2.0 (Brown et al., 1999). Sedangkan data klor-a dari sensor MODIS diproduksi berdasarkan algoritma ocean chlorophyll algorithm (OCx) (O'Reilly et al., 1998), yang dikombinasikan dengan Color Index Based Algorithm (CIA) (Hu et al., 2012).

Analisis multilayer upwelling bisa dilakukan dengan menggunakan data ARGO Float, yaitu suatu wahana yang dapat merekam data oseanografi secara otomatis dan mengirimkan datanya ke database. ARGO Float dilepaskan di laut lepas dan kemudian akan secara otomatis tenggelam ke kedalaman 2000 meter. Setiap 10 hari sekali alat tesebut akan naik ke permukaan sambil merekam data temperatur dan salinitas pada beberapa kedalaman. Begitu muncul ke permukaan maka data hasil perekaman akan dikirimkan ke database melalui satelit (Gould et al., 2005). Wahana ARGO Float mulai dikembangkan dan digunakan pada tahun 1954 . Hingga tahun 2004 telah lebih dari 1500 wahana ARGO Float yang dilepaskan di seluruh dunia yang memberikan data global untuk berbagai kepentingan (Gould et al., 2005). Data dari ARGO Float yang terkumpul di database kemudian di validasi terlebih dahulu sebelum digunakan untuk berbagai analisis. Validasi dilakukan dengan mengaplikasikan berbagai macam metode kontrol kualitas (Gaillard et al., 2009). Dengan menggunakan data ARGO Float 
Pranowo et al. (2005), menganalisis karakteristik dan dinamika massa air di Samudera Hindia (perairan selatan Jawa). Penggunaan data ARGO Float pada penelitian tersebut memberikan kontribusi yang sangat signifikan terhadap pemahaman respon vertikal dan data insitu dari laut dalam (subsurface).

Dalam penelitian ini penggunaan data SPL dan Klor-a dari data satelit serta subsurface temperature pada beberapa kedalaman yang diperoleh dari data Argo Float akan memberikan gambaran yang lebih detil mengenai variabilitas upwelling secara spasiotemporal serta vertikal di perairan selatan Jawa serta pengaruh ENSO dan IOD terhadap intensitas upwelling di wilayah tersebut.

\section{BAHAN DAN METODE}

Pada penelitian ini, analisis variabilitas upwelling dilakukan di perairan selatan Jawa pada lintang $7^{\circ} \mathrm{S}$ hingga $14^{\circ} \mathrm{S}$ dan $105^{\circ} \mathrm{BT}$ hingga $117^{\circ} \mathrm{BT}$. sebagaimana pada gambar 1. Data SPL dan Klor-a diperoleh dari data satelit MODIS level 3 bulanan selama 11 tahun pada periode 2007-2017. Resolusi spasial yang digunakan pada penelitian ini adalah $4 \mathrm{~km}$. Data yang digunakan adalah data siang hari. Dari data satelit global yang di unduh dari website https://oceancolor.gsfc.nasa.gov/ cgi/13 . Data SPL dan Klor musim timur didapatkan dari rata-rata bulan Juni, Juli dan Agustus, sedangkan musim barat diolah dari data bulan Desember, Januari dan Februari. Data subsurface temperature dari data ARGO float yang diunduh dari data website http:// www.argo.ucsd.edu/. Data yang digunakan meliputi data subsurface temperature pada kedalaman $100 \mathrm{~m}$, dan $200 \mathrm{~m}$ dan $500 \mathrm{~m}$ serta profil suhu dari permukaan hingga kedalaman $500 \mathrm{~m}$. Hal ini berdasarkan pada Pranowo et al. (2005), yang menemukan bahwa pada periode tertentu proses downwelling bisa mencapai kedalaman lebih dari $400 \mathrm{~m}$.

Untuk melihat pengaruh Samudera Pasifik kepada Laut Selatan Jawa maka dilakukanlah analisis menggunakan index el nino. Indeks el nino mengacu pada Oceanic Nino Index (ONI) yang dikembangkan oleh NOAA Climate Prediction Center yang diunduh dari website http://origin.cpc.ncep.noaa.gov/products/analysis monitoring/ensostuff/ONI_v5.php yang dibuat berdasarkan pada analisis anomali SST 3 bulanan antara $5^{\circ} \mathrm{N}-5^{\circ} \mathrm{S}$ dengan $120^{\circ}-170^{\circ} \mathrm{W}$ dengan threshold sebesar $0,5^{\circ} \mathrm{C}$ dimana indeks diatas 0,5 adalah periode el nino sedangkan indeks dibawah -0.5 adalah periode la nina Sedangkan untuk melihat pengaruh Samudera Hindia kepada Laut Selatan Jawa dapat dilakukan dengan menganalisis index IOD. Indeks IOD menggunakan indeks yang dikembangkan oleh Global Climate Observing System (GCOS) Working Group on Surface Pressure (WG-SP) yang diunduh dari website https://www.esrl.noaa.gov/psd/gcos_wgsp/Timeseries/ Data/dmi.long.data. Indeks IOD didasarkan pada anomali SST antara western equatorial Indian Ocean

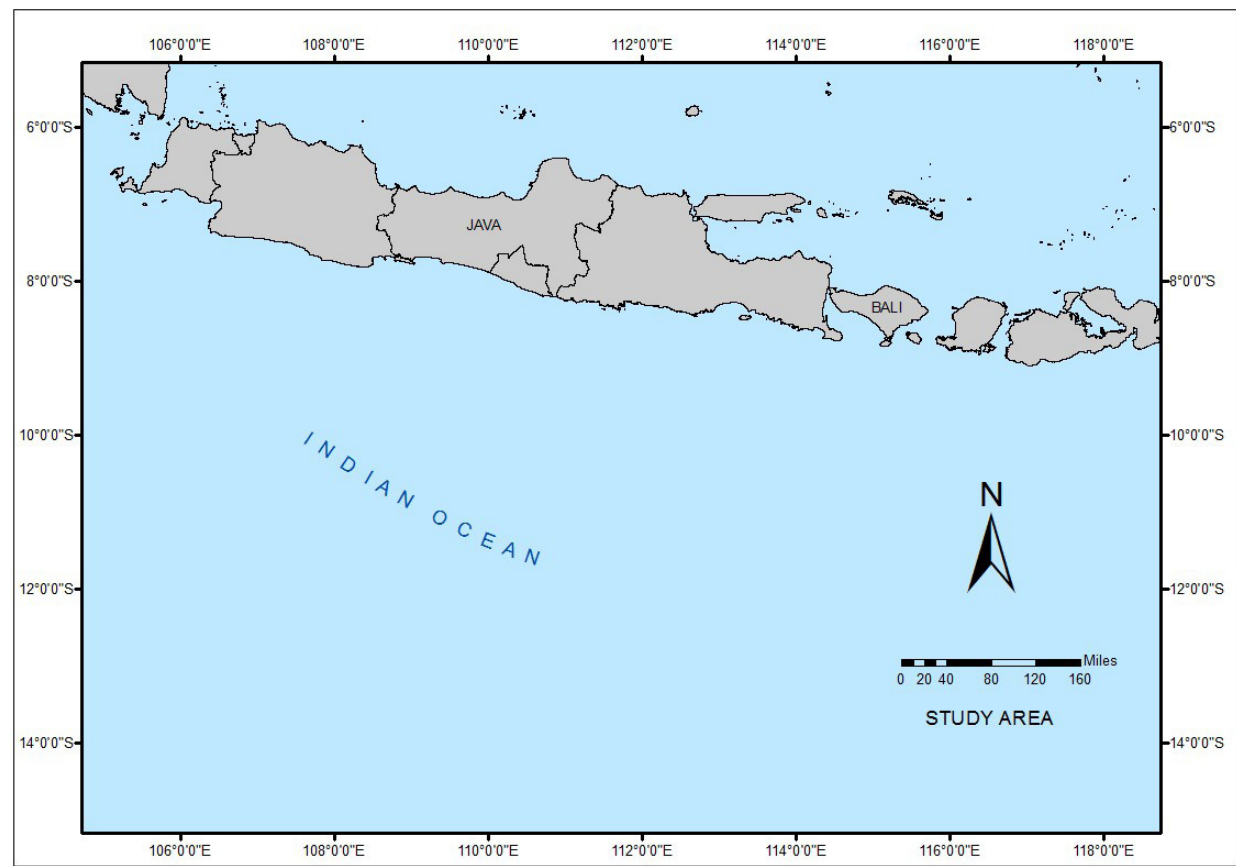

Gambar 1. Daerah Penelitian di perairan Selatan Jawa.

Figure 1. Research Area in South Java Sea. 
$\left(5^{\circ} \mathrm{E}-7^{\circ} \mathrm{E}\right.$ and $\left.1^{\circ} \mathrm{S}-1^{\circ} \mathrm{N}\right)$ dengan the south eastern equatorial Indian Ocean $\left(9^{\circ} \mathrm{E}-11^{\circ} \mathrm{E}\right.$ and $\left.1^{\circ} \mathrm{S}-0^{\circ} \mathrm{N}\right)$. Indeks yang nilainya positif menunjukkan periode IOD positif sedangkan indeks yang nilainya negatif merepresentasikan periode IOD negatif.

Korelasi antar variabel dilakukan dengan korelasi Pearson (Silverman, 2003), sebagai Berikut :

$$
r=\frac{\sum x y-\frac{\left(\sum x\right)\left(\sum y\right)}{n}}{\sqrt{\left(\sum x^{2}-\frac{\left(\sum x\right)^{2}}{n}\right)\left(\sum y^{2}-\frac{\left(\sum y\right)^{2}}{n}\right)}}
$$

Dimana :

$$
\begin{array}{ll}
\mathrm{x} & \text { : nilai variabel } \mathrm{x} \\
\mathrm{y} & : \text { nilai variabel } \mathrm{y} \\
\mathrm{n} & \text { : jumlah variabel }
\end{array}
$$

\section{HASIL DAN PEMBAHASAN}

\section{Variabilitas SPL}

SPL di perairan selatan Jawa mengalami fluktuasi musiman. Pada MT, SPL relatif lebih dingin dibandingkan pada musim barat. Gambar 2.a. menunjukan rata-rata SPL pada musim barat yang direpresentasikan oleh data satelit pada bulan Desember, Januari dan Februari dari tahun 2007 hingga tahun 2017. SPL di perairan selatan Jawa pada musim barat memiliki kisaran suhu antara $28^{\circ} \mathrm{C}$ hingga $31,2^{\circ} \mathrm{C}$ dimana semakin ke selatan SPL nya semakin dingin. Sebaliknya pada MT sebagaimana pada Gambar 2.b. terlihat bahwa SPL di perairan selatan Jawa relatif lebih dingin dibandingkan pada musim barat. SPL pada musim timur berkisar antara antara $25^{\circ} \mathrm{C}$ hingga $29^{\circ} \mathrm{C}$.
SPL pada tahun 2016 secara umum memiliki variabilitas yang lebih tinggi dibandingkan SPL pada tahun - tahun sebelumnya, bahkan lebih tinggi jika dibandingkan dengan SPL tahun 2017. Hal ini dimungkinkan karena adanya pengaruh el nino yang mengalami penguatan pada tahun 2015 dan diikuti la nina pada tahun 2016 . El nino pada tahun 2015 ditandai dengan index yang tinggi sepanjang tahun hingga mencapai 2,6 yang terjadi pada bulan Desember 2015 dan mulai menurun hingga bulan Mei 2016, kemudian index menunjukan nilai negatif sebagai tanda terjadinya periode la nina hingga mencapai angka -7 pada bulan September hingga November 2016.

Hasil analisis mengenai variabilitas musiman SPL di perairan selatan Jawa sesuai dengan penelitian sebelumnya sebagaimana Kunarso (2012), yang menyatakan bahwa SPL di daerah tersebut mengalami fluktuasi musiman dengan suhu terdingin pada musim timur. Ningsih et al. (2013), lebih lanjut mengemukakan bahwa SPL didaerah tersebut pada musim timur berkisar antara $24,5^{\circ} \mathrm{C}$ hingga $28,0^{\circ} \mathrm{C}$, sedangkan pada musim barat berkisar antara $28,7^{\circ} \mathrm{C}$ hingga $30,2^{\circ} \mathrm{C}$.

\section{Variabilitas Klor-a}

Konsentrasi klor-a di perairan selatan Jawa juga mengalami fluktuasi musiman sebagaimana terlihat pada gambar 4.a. dan 4.b. dimana pada musim timur klor-a lebih tinggi $\left(0,1-1,25 \mathrm{mg} / \mathrm{m}^{3}\right)$ dibandingkan pada musim barat $\left(0,09-0,48 \mathrm{mg} / \mathrm{m}^{3}\right)$. Pada musim barat (Gambar 4.a.) terlihat bahwa klor-a relatif rendah yang direpresentasikan dengan warna biru. Klor-a dengan konsentrasi yang agak tinggi hanya terlihat sedikit di dekat pesisir pulau Jawa dengan distribusi yang tidak

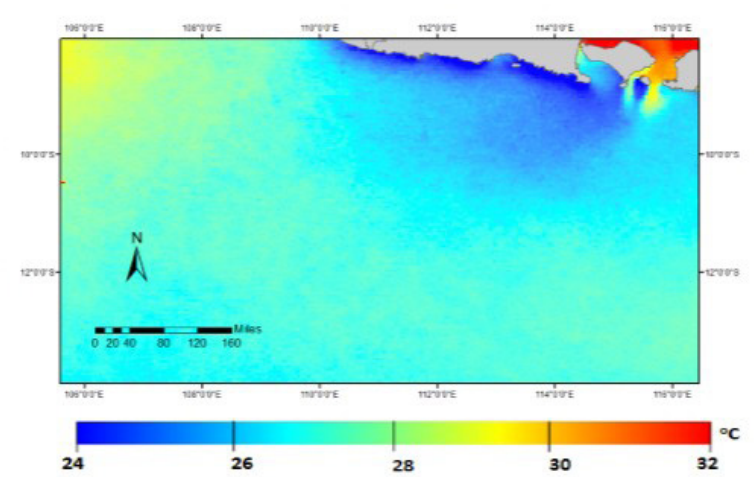

Gambar 2b. SPL musim timur (rata-rata SPL bulan JJA periode 2007-2017).

Figure 2b. East Monsoon SST (montly average JJA period: 2007-2017). 


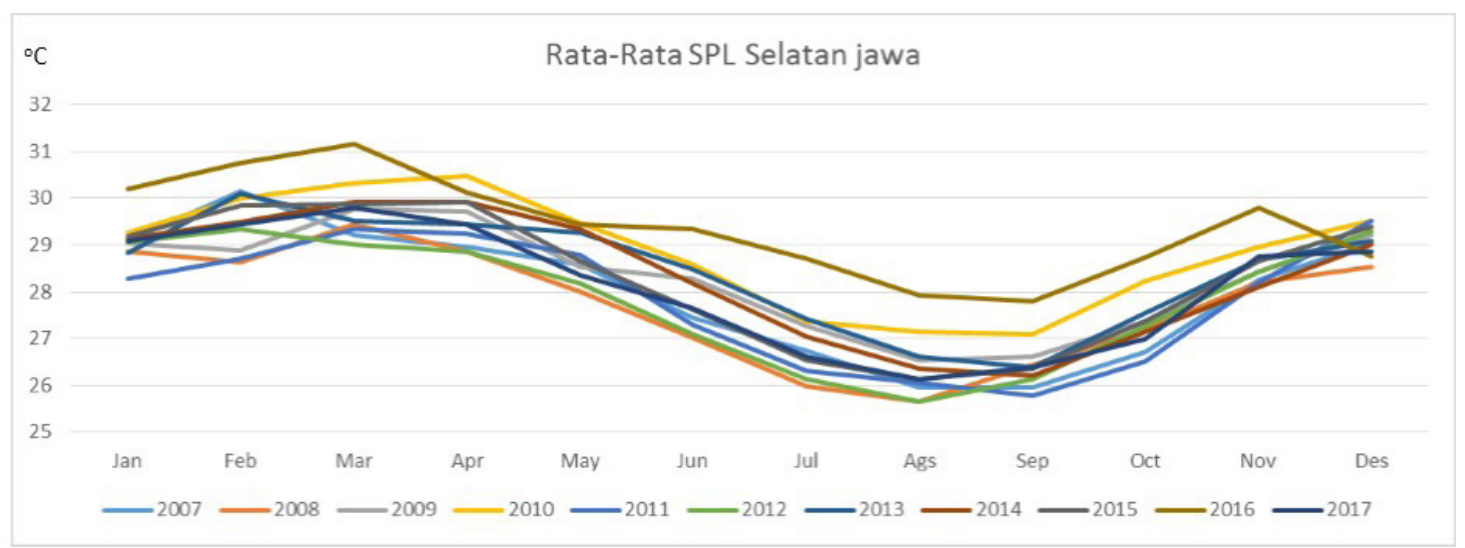

Gambar 3. Grafik variabilitas SPL rata-rata bulanan periode 2007-2017.

Figure 3. Monthly average of SST variability during period 2007-2017.

terlalu jauh, tidak lebih dari 20 mil laut. Sebaliknya pada musim timur (Gambar 4.b.) klor-a terlihat sangat tinggi yang direpresentasikan dengan warna kuning hingga merah dengan distribusi spasial yang cukup luas dari timur hingga barat dengan persebaran yang cukup jauh dari garis pantai hingga lebih dari 40 mil laut.

Ektraksi data satelit dilakukan untuk mendapatkan nilai rata-rata konsentrasi klor-a dari permukaan laut hingga kedalaman sekitar 40 m (Stramska \& Stramski, 2005). Dari grafik bulanan konsentrasi klor-a sebagaimana pada Gambar 5. Terlihat bahwa konsentrasi klor-a mulai mengalami peningkatan pada bulan Maret April dan mengalami puncaknya pada bulan AgustusSeptember pada kisaran antara $0,40 \mathrm{mg} / \mathrm{m}^{3}$ hingga $0,55 \mathrm{mg} / \mathrm{m}^{3}$. Kondisi yang berbeda terlihat pada tahun 2016 dimana klor-a tidak mengalami peningkatan sebagaimana tahun tahun sebelumnya. Peningkatan konsentrasi klor-a hanya terlihat mulai pada bulan Maret dan mencapai puncaknya pada bulan April

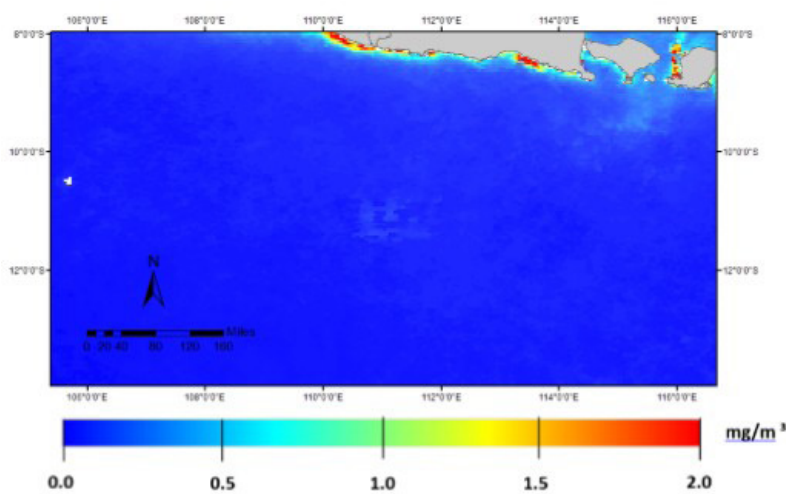

Gambar 4a. Klor-a musim barat (rata-rata SPL bulan DJF periode 2007-2017).

Figure 4a. West Monsoon Klor-a (monthly average of DJF period: 2007-2017). namun tidak lebih dari $0.2 \mathrm{mg} / \mathrm{m}^{3}$, bahkan pada bulan Juli hingga September dimana seharusnya merupakan bulan dimana klor-a mencapai puncak konsentrasinya, ternyata pada tahun 2016 justru lebih rendah dibandingkan pada bulan April. Hal ini dimungkinkan karena terjadinya periode la nina sebagaimana telah dijelaskan diatas. Secara umum variabilitas klor-a berbanding terbalik dengan variabilitas SPL. Pada saat SPL mengalami peningkatan maka konsentrasi klor-a justru mengalami penurunan.

Variabilitas musiman klor-a di perairan selatan Jawa diatas, sesuai dengan pernyataan Iskandar et al. (2009), yang menyatakan bahwa klor-a mengalami pertumbuhan yang sangat signifikan pada Musim Barat dan mengalami puncaknya pada bulan AgustusSeptember, kemudian mengalami penurunan yang sangat cepat pada bulan November. Demikian Juga Ningsih et al. (2013), mengemukakan bahwa pada Musim Barat konsentrasi klor-a berkisar antara 0,11-2,21 $\mathrm{mg} / \mathrm{m}^{3}$ sedangkan pada musim timur

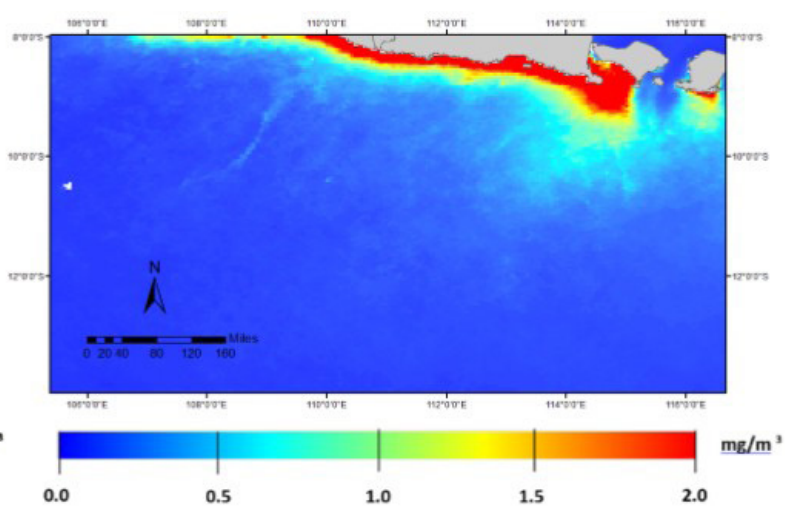

Gambar 4b. Klor-a musim timur (rata-rata SPL bulan JJA periode 2007-2017).

Figure 4b. East of east season (average SST month JJA period 2017-2017). 


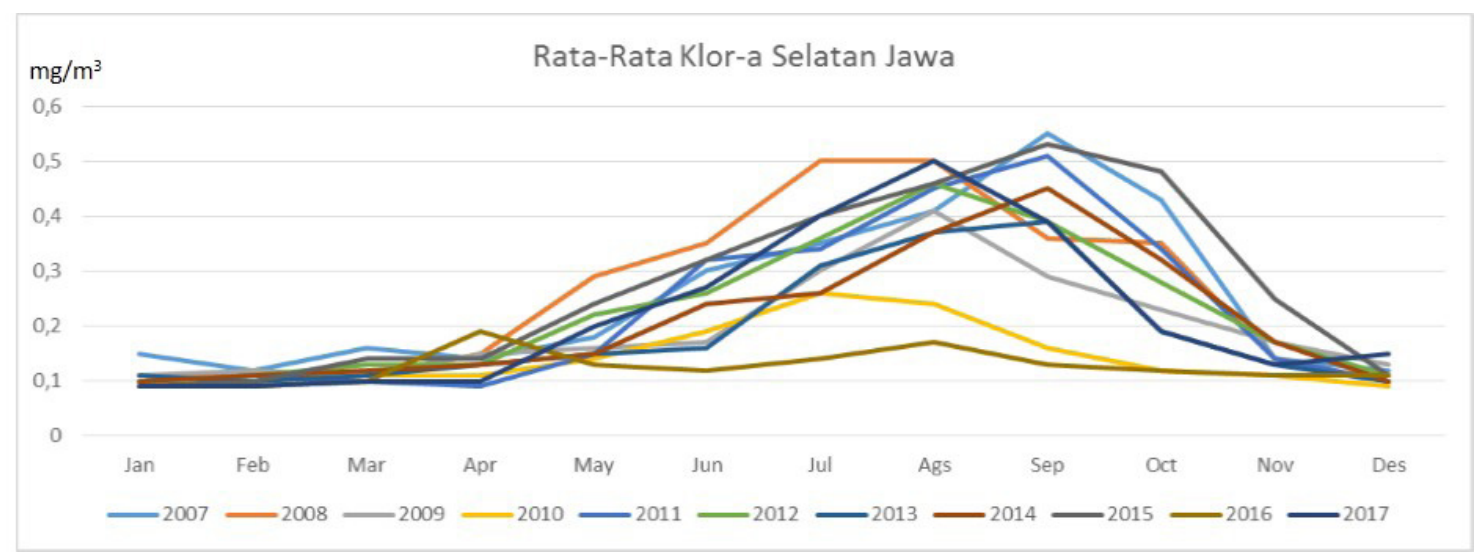

Gambar 5. Grafik Variabilitas Klor-a rata-rata bulanan periode 2007-2017.

Figure 5. Monthly average of Klor-a Variability for the period: 2007-2017.

konsentrasinya jauh lebih tinggi antara $0,42-5,31 \mathrm{mg} /$ $\mathrm{m}^{3}$.

\section{Korelasi SST Dan Klorofil-a}

Jika variabilitas SPL dioverlay dengan klor-a, maka akan terlihat korelasi yang kuat antar kedua data tersebut. Gambar 6. Menunjukkan sebuah pola fluktuasi yang unik dimana secara bulanan kedua data tersebut saling berkait.

Besaran nilai SPL dari data satelit merupakan representasi dari skin temperature yang berada pada lapisan tipis di permukaan laut sekitar $550 \mu \mathrm{m}$ yang kemudian di validasi menggunakan data in situ pada lapisan bulk temperature pada kedalaman hingga sekitar $5 \mathrm{~m}$ (Donlon et al., 2002). Untuk konsentrasi klor-a merupakan rata-rata dari permukaan laut hingga kedalaman sekitar 40 m (Stramska \& Stramski, 2005).

Pada saat SPL mengalami penurunan, konsentrasi klor-a mengalami peningkatan, demikian juga sebaliknya pada saat SPL mengalami kenaikan ternyata klor-a mengalami penurunan. Time lag peningkatan klor-a yang mengikuti penurunan SPL terjadi kurang dari satu bulan sebagaimana terlihat misalnya ketika SPL mulai mengalami penurunan pada bulan Maret 2017, diikuti oleh kenaikan klor-a pada bulan April 2017. Dari analisis korelasi menggunakan korelasi Pearson, didapatkan nilai korelasi sebesar -0.89 yang menunjukkan bahwa fluktuasi konsentrasi klor-a berkorelasi sangat kuat dengan fluktuasi SPL.

\section{Analisis Multilayer Fenomena Upwelling}

Variabilitas SPL di perairan selatan Jawa dipengaruhi oleh terjadinya upwelling. Pada MT ketika angin bertiup ke arah barat menyebabkan terjadinya upwelling dan membawa air dari lapisan bawah menuju ke permukaan meyebabkan SPL menjadi lebih dingin (Susanto, 2001). Profil upwelling dan downwelling dapat dilihat pada gambar 7. Sedangkan subsurface temperatur pada beberapa kedalaman terlihat pada Gambar 8.a. dan Gambar 8.b.

Dari Gambar 7. Terlihat bahwa upweling dan downwelling terjadi secara berulang. Pada musim timur massa air dingin naik ke permukaan, sedangkan pada musim barat massa air hangat turun ke kedalaman, bahkan pada periode tertentu seperti pada tahun 2014 ,

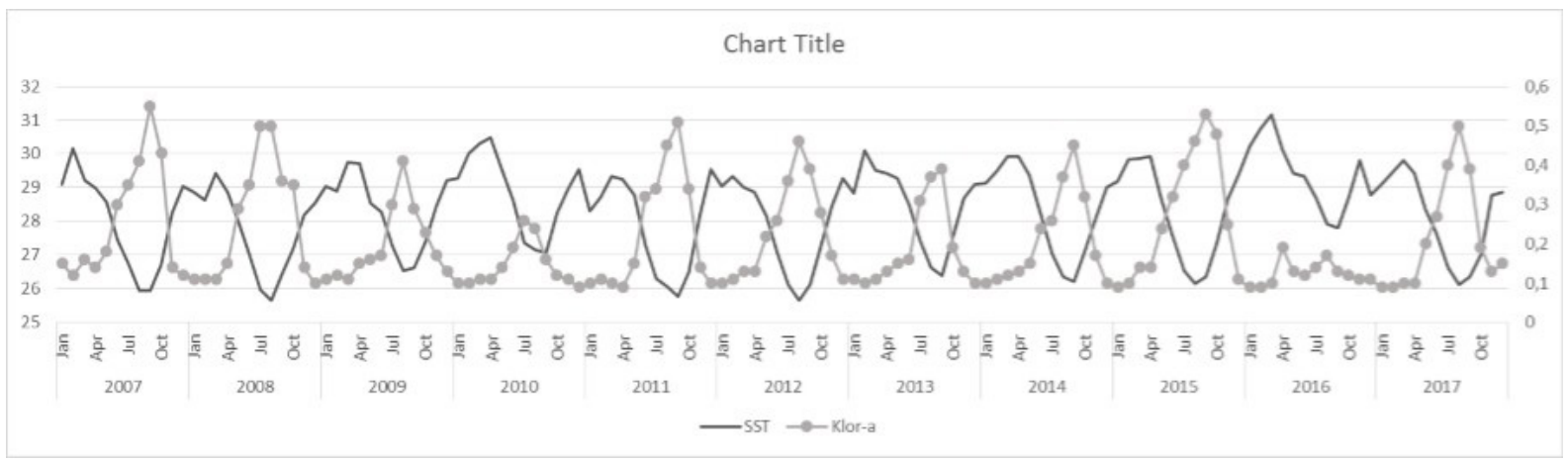

Gambar 6. Variabilitas SPL dan Klor-a rata-rata bulanan periode 2007-2017.

Figure 6. Variability of SST and Chlorrophyll-a monthly average for the period 2007-2017. 


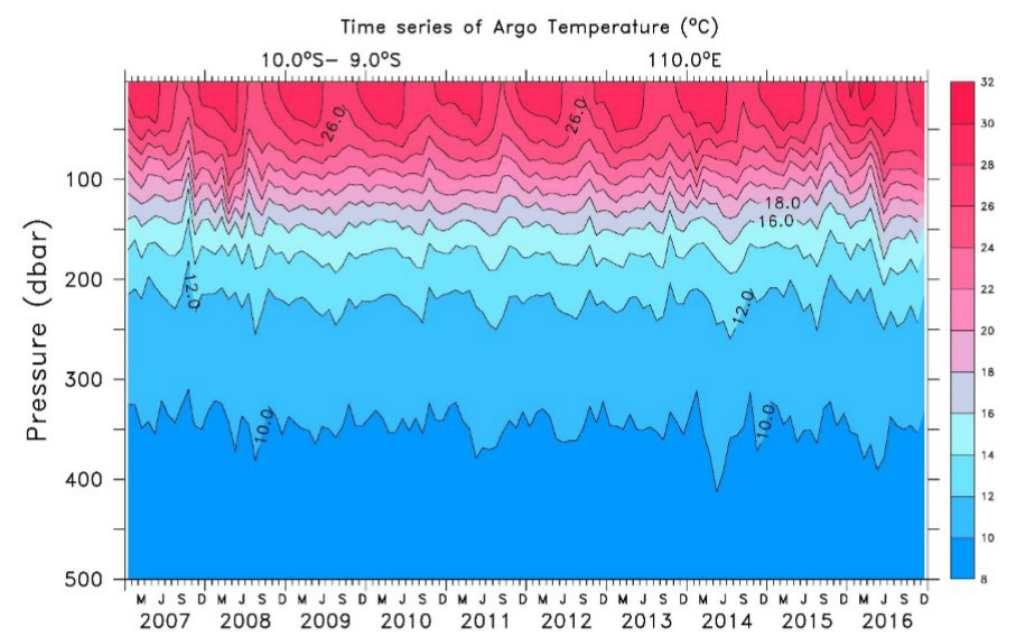

Gambar 7. Profil Upwelling dan downwelling dari permukaan laut hingga kedalaman $500 \mathrm{~m}$.

Figure 7. Upwelling and downwelling profile from surface to $500 \mathrm{~m}$ depth.
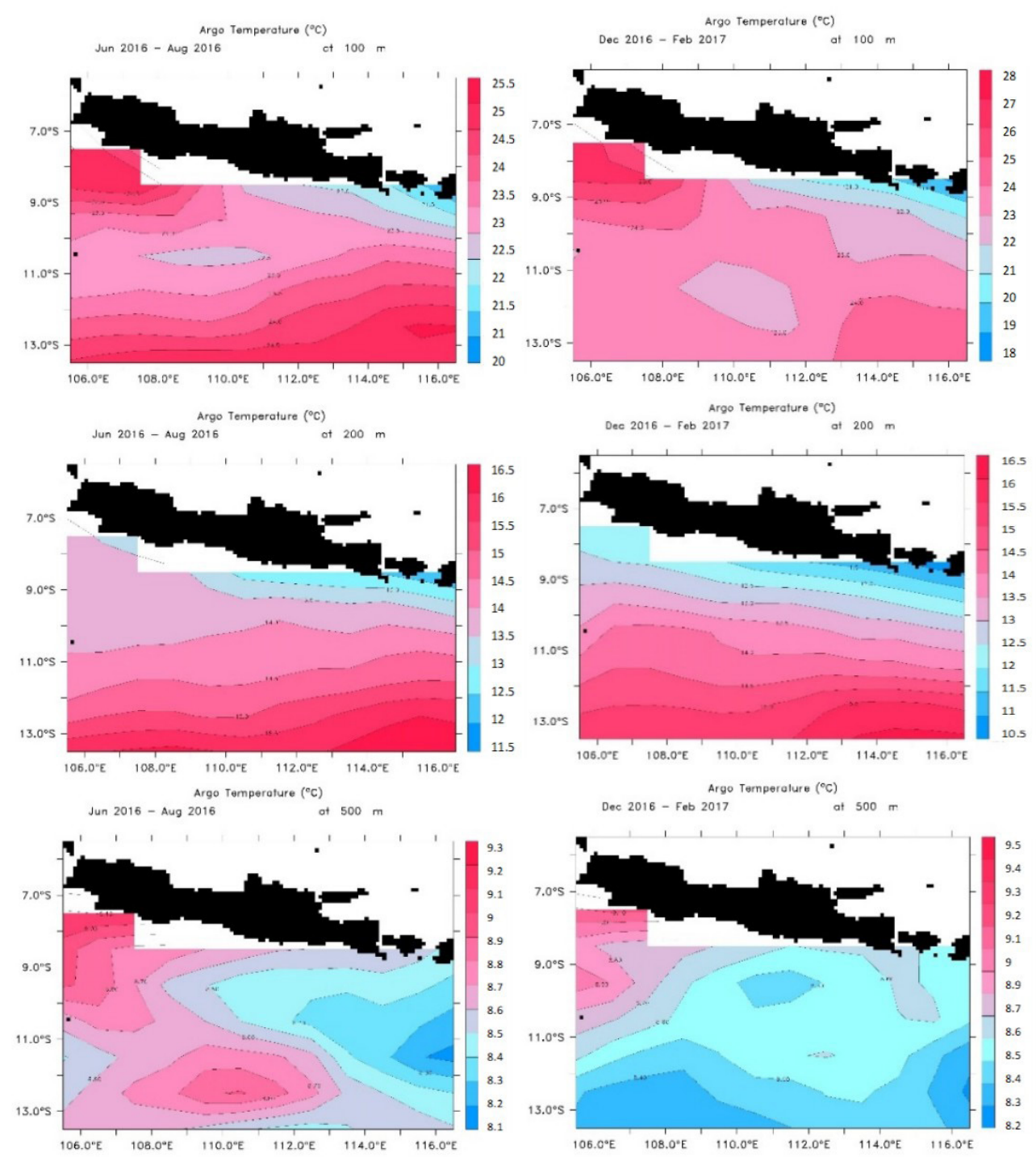

Gambar 8a. Subsurface temperature di kedalaman $100 \mathrm{~m}$, $200 \mathrm{~m}$ dan $500 \mathrm{~m}$ pada musim timur.

Figure 8a. Subsurface temperature at depth $100 \mathrm{~m}$, $200 \mathrm{~m}$ and $500 \mathrm{~m}$ during East Monsoon.

Gambar 8b. Subsurface temperature di kedalaman 100 m, $200 \mathrm{~m}$ dan $500 \mathrm{~m}$ pada musim barat.

Figure $8 b$. Subsurface temperature at depths of $100 \mathrm{~m}$, $200 \mathrm{~m}$ and $500 \mathrm{~m}$ during West Monsoon. 
downwelling mencapai hingga lebih dari $400 \mathrm{~m}$.

Naiknyamassaairdarilapisanbawahmenujupermukaan belum terlihat pada kedalaman $500 \mathrm{~m}$. Perbedaan suhu pada antara musim barat dan musim timur terlihat jelas pada kedalaman $200 \mathrm{~m}$ dan $100 \mathrm{~m}$, dimana pada musim timur (Gambar 8.a) suhu di perairan selatan Jawa lebih rendah sekitar $2^{\circ} \mathrm{C}$ dibandingkan pada musim barat (Gambar 8.b), khususnya di sepanjang pesisir Pulau Jawa hingga sekitar lintang $11^{\circ} \mathrm{S}$. Varela et al. (2016), menyatakan bahwa penurunan SPL di sepanjang pesisir Jawa menyebar ke arah selatan menuju laut lepas. Terdapat perbedaan SPL yang cukup tinggi antara perairan pesisir dengan perairan di laut lepas di selatan jawa yang berkisar sekitar $2{ }^{\circ} \mathrm{C}$ dengan SPL yang lebih dingin di dekat pesisir Jawa. Profil anomali suhu dari permukaan hingga kedalaman $200 \mathrm{~m}$ menunjukan terjadinya upwelling di perairan selatan Jawa sepanjang bulan Juli hingga Oktober. Trend penurunan suhu akibat terjadinya upwelling mulai terlihat pada kedalaman $180 \mathrm{~m}$ dan meningkat seiring dengan kedalaman hingga mencapai puncak penurunan suhu pada kedalaman sekitar $100 \mathrm{~m}$ dengan penuruan suhu sekitar $-0,5^{\circ} \mathrm{C}$.

\section{Pengaruh ENSO Terhadap Upwelling}

ENSO memberikan pengaruh yang kuat terhadap upwelling di perairan selatan Jawa. Variabilitas upwelling sebagai akibat dari pengaruh ENSO kemudian menyebabkan fluktuasi SPL yang lebih hangat maupun lebih dingin dibandingkan kondisi normal. Hal ini terkonfirmasi pada Gambar 9. Dimana pada periode el nino yang ditandai dengan indeks ONI yang lebih tinggi dari 0,5 akan diikuti dengan penurunan SPL hingga lebih dari $3^{\circ} \mathrm{C}$, sebaliknya pada periode la nina dimana indeks ONI lebih rendah dari - 0.5 akan diikuti dengan SPL yang lebih hangat. Korelasi antara ENSO dengan SPL adalah sebesar $-0,78$.

Susanto et al. (2001), menjelaskan bahwa area yang paling terpengaruh oleh upwelling adalah disepanjang pesisir Jawa dan Sumatera. Upwelling kuat yang terjadi di daerah tersebut dideteksi sebagai akibat pengaruh terjadinya ENSO kondisi tersebut kemudian memicu penurunan SPL.

Selain mempengaruhi SPL, variabilitas upwelling sebagai respons terhadap ENSO juga mempengaruhi konsentrasi klor-a. Gambar 10. Menunjukan bahwa

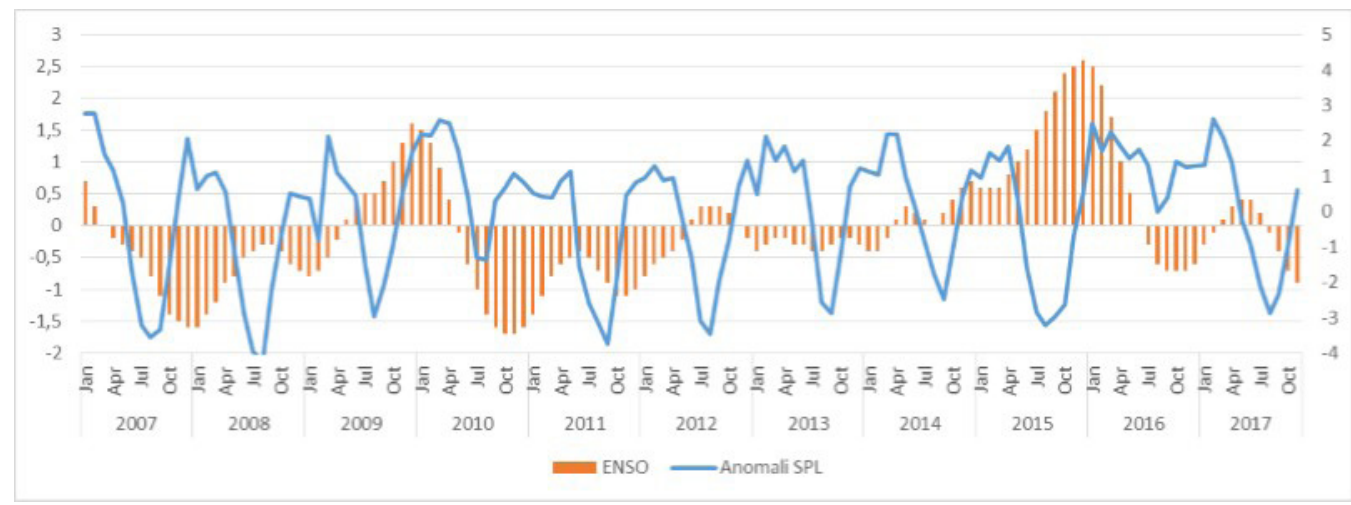

Gambar 9. Anomali SPL di overlay dengan indeks ENSO.

Figure 9. SST anomaly overlays with ENSO index.

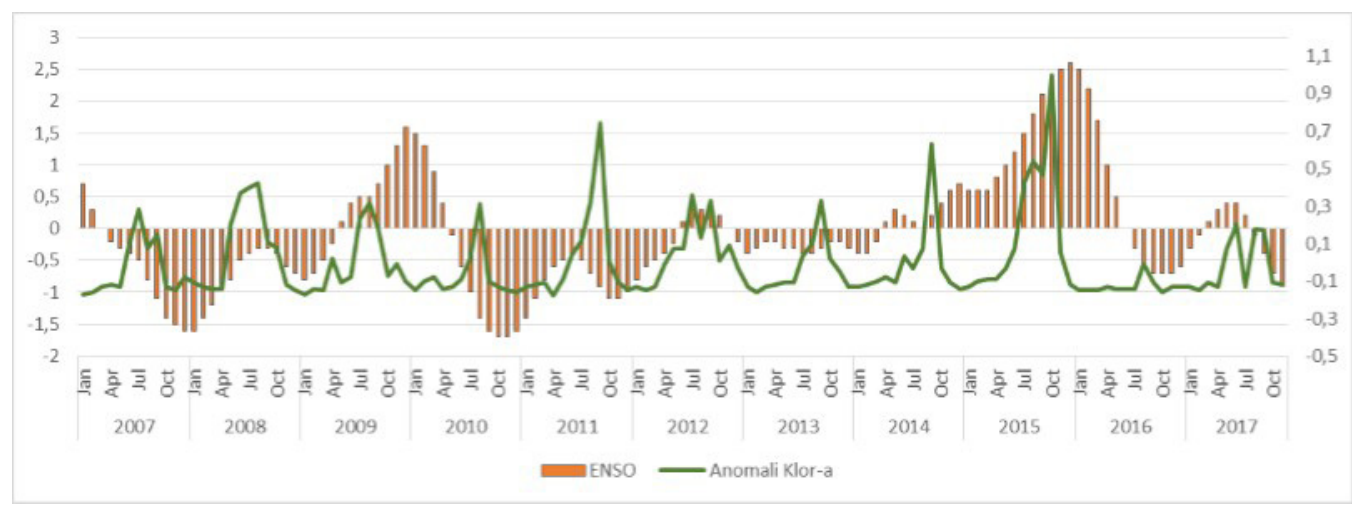

Gambar 10. Anomali Klor-a di overlay dengan indeks ENSO.

Figure 10. Chlor-a anomaly overlays with ENSO index. 


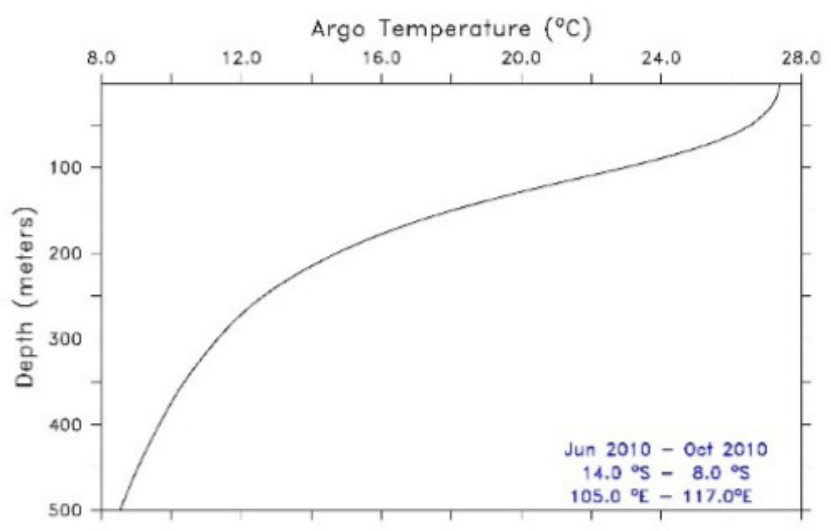

Gambar 11. Profil subsurface temperature pada periode el nino (garis merah) dan la nina (garis hitam).

Figure 11. Profile subsurface temperature in el nino period (red line) and la nina (black line).

periode el nino diikuti dengan naiknya klor-a, sebaliknya periode la nina menyebabkan penurunan klor-a. Korelasi antara ENSO dengan klor-a adalah sebesar 0,76 .

Pengaruh ENSO terhadap klor-a melalui mekanisme upwelling ini sesuai dengan penelitian Susanto \& Marra (2005), yang menemukan bahwa pada periode el nino, klor-a mengalami peningkatan konsentrasi lebih tinggi daripada kondisi mormal. Demikian juga dengan penelitian yang dilakukan oleh Ningsih et al. (2013), yang menjelaskan bahwa ENSO memberikan pengaruh yang kuat terhadap klor-a baik pada periode el nino maupun la nina.

Pengaruh ENSO terhadap SPL dan subsurface temperature akan terlihat jelas pada profil suhu dari permukaan hingga ke lapisan perairan yang lebih dalam sebagaimana pada Gambar 11. Pada periode la nina SPL relatif lebih hangat dibandingkan kondisi normal. Terlihat bahwa SPL musim timur yang diwakili oleh rata-rata bulan Juni - Oktober 2010 memiliki kisaran antara $27^{\circ} \mathrm{C}-28^{\circ} \mathrm{C}$, kemudian suhu relatif stabil hingga kedalaman sekitar $100 \mathrm{~m}$, menandakan bahwa upwelling di daerah tersebut relatif lemah. Dibawah 100 $\mathrm{m}$ subsurface temperature kemudian menurun secara cepat seiring dengan kedalaman. Sebaliknya pada periode el nino SPL relatif lebih dingin dibandingkan kondisi normal. SPL berkisar antara $26^{\circ} \mathrm{C}-27^{\circ} \mathrm{C}$, suhu tersebut segera mengalami penurunan secara cepat pada kedalaman kurang dari $50 \mathrm{~m}$, hal menandakan bahwa upwelling di daerah tersebut sangat kuat.

\section{Pengaruh IOD Terhadap Upwelling}

Upwelling di perairan selatan Jawa juga mendapatkan pengaruh yang sangat kaut dari IOD. Gambar 12. menunjukan korelasi yang kuat antara SPL dengan IOD melalui mekanisme upwelling. Periode IOD + yang ditandai dengan indeks IOD diatas 0,5 akan diikuti dengan penurunan SPL yang lebih rendah daripada kondisi normal, sebaliknya pada periode IOD negatif akan diikuti dengan naiknya SPL.

Pengaruh IOD terhadap SPL juga dinyatakan oleh Du et al. (2008), dimana IOD akan menyebabkan

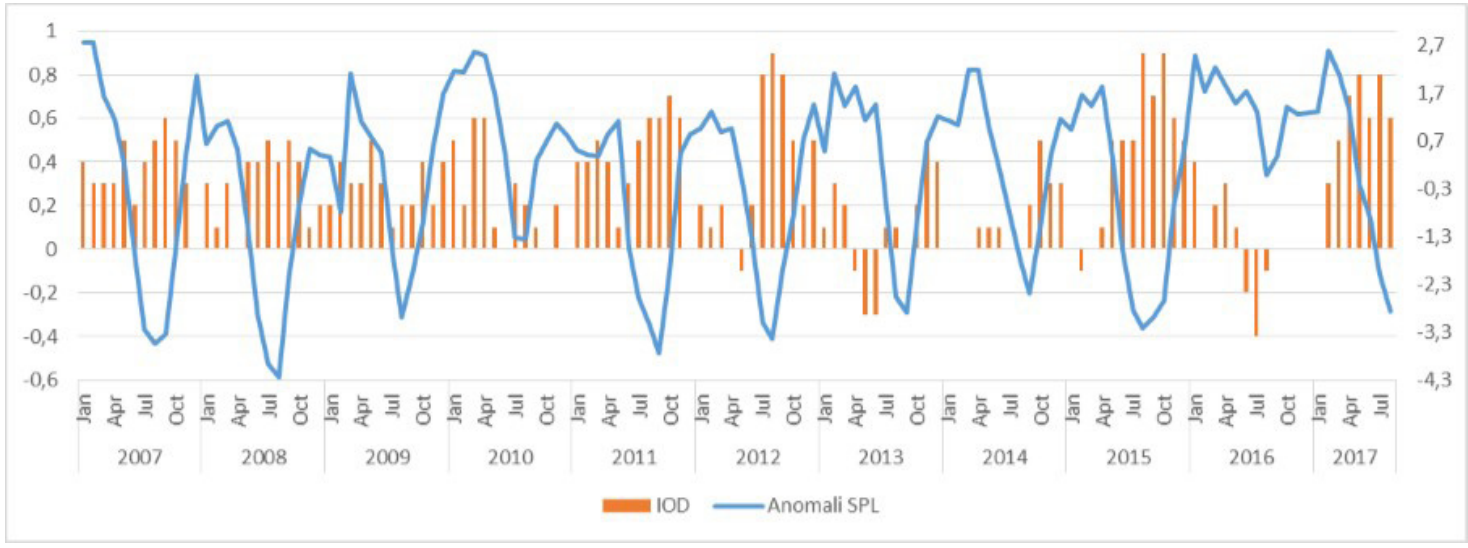

Gambar 12. Anomali SPL di overlay dengan indeks IOD.

Figure 12. SST anomaly overlays with IOD index. 


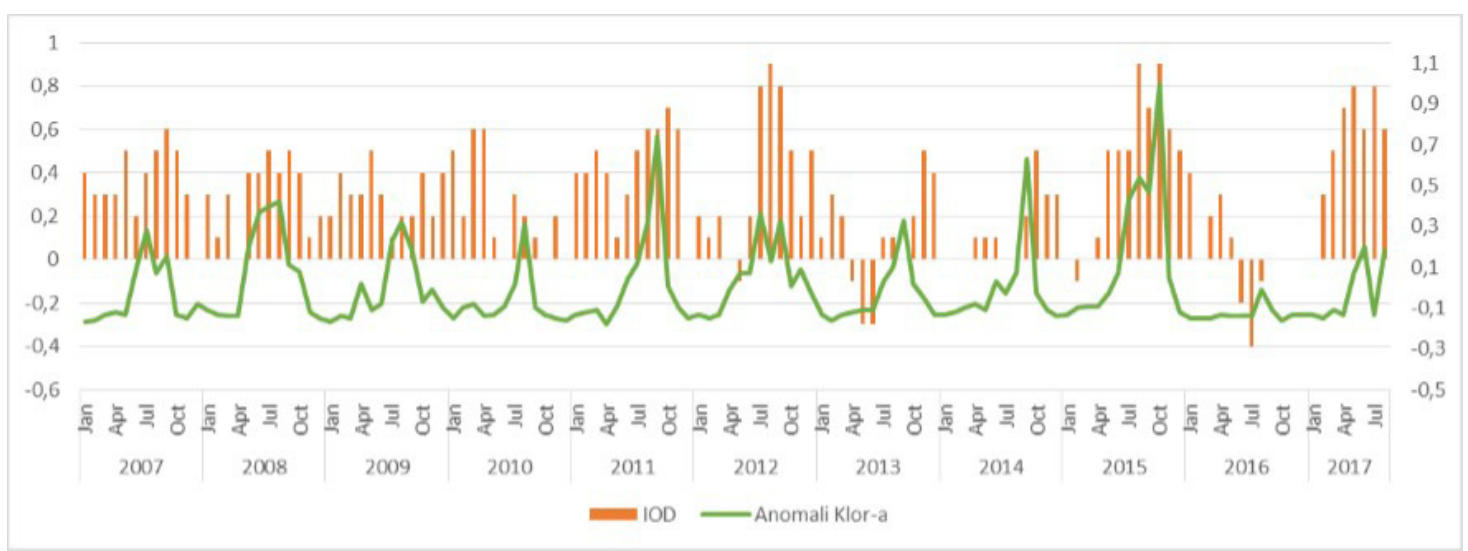

Gambar 13. Variabilitas Klor-a di overlay dengan index IOD.

Figure 13. Chlor-a variability overlays with IOD index.

terjadinya anomali SPL sepanjang perairan JawaSumatera, bahkan pada periode IOD positif anomali SPL bisa mencapai $-3^{\circ} \mathrm{C}$. Korelasi antara IOD dengan SPL adalah sebesar $-0,88$.

Konsentrasi klor-a akan mengalami peningkatan lebih besar dibandingkan kondisi normal pada saat terjadi IOD positif, sebaliknya akan mengalami penurunan pada saat IOD negatif, hal ini terlihat jelas pada Gambar 13.

Periode IOD positif memicu naiknya intensitas upwelling di selatan Jawa yang kemudian menyebabkan meningkatnya konsentrasi klor-a. Anomali peningkatan konsentrasi klor-a sebagai respons terhadap IOD mencapai lebih dari $1 \mathrm{mg} / \mathrm{m}^{3}$ (Rahul et al., 2008). Lebih jauh Ningsih et al. (2013), menemukan bahwa jika periode IOD + dibarengi dengan periode el nino maka peningkatan konsentrasi klor-a mencapai anomali lebih dari $4,5 \mathrm{mg} / \mathrm{m}^{3}$. Korelasi antara IOD dengan klor-a adalah sebesar 0,81 .

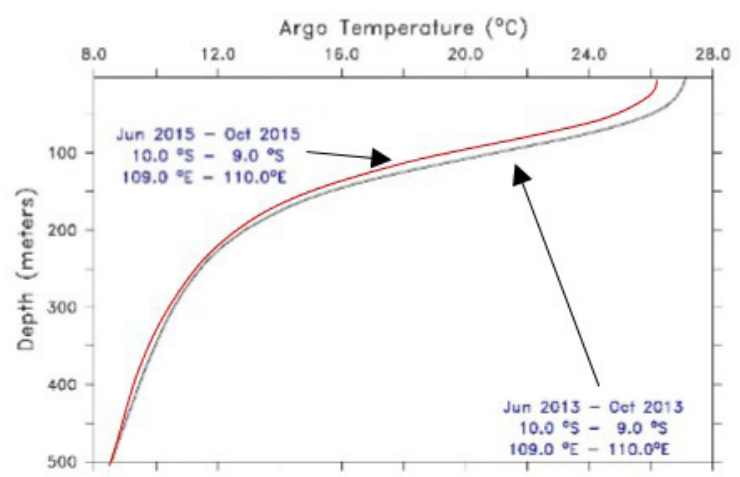

Gambar 14. Profil subsurface temperature pada periode IOD negatif (garis hitam) dan IOD positif (garis merah).

Figure 14. Profile subsurface temperature in negative IOD period (black line) and positive IOD (red line).
Profil suhu dari permukaan hingga kedalaman 500m sebagaimana pada Gambar 14. menjelaskan perbedaan pengaruh IOD positif dengan IOD negatif terhadap intensitas upwelling di selatan Jawa. Pada periode IOD negatif intensitas upwelling relatif melemah yang ditandai dengan SPL sekitar $27^{\circ} \mathrm{C}-28^{\circ} \mathrm{C}$ yang relatif stabil hingga kedalaman sekitar $100 \mathrm{~m}$. Kondisi sebaliknya pada periode IOD positif terlihat bahwa intensitas upwelling mengalami peningkatan yang ditandai dengan SPL sekitar $26^{\circ} \mathrm{C}-27^{\circ} \mathrm{C}$ yang kemudian pada kedalaman kurang dari $50 \mathrm{~m}$ mengalami penurunan drastis seiring dengan bertambahnya kedalaman.

\section{KESIMPULAN DAN SARAN}

Secara umum SPL dan klor-a mengalami fluktuasi secara musiman. SPL Pada musim barat $\left(28-31,2^{\circ} \mathrm{C}\right)$ relatif lebih tinggi dibandingkan pada musim timur $\left(25-29^{\circ} \mathrm{C}\right)$, namun sebaliknya klor-a pada musim barat $\left(0.09-0,48 \mathrm{mg} / \mathrm{m}^{3}\right)$ justru lebih rendah dibandingkan pada musim timur $\left(0,1-1,25 \mathrm{mg} / \mathrm{m}^{3}\right)$.variabilitas SPL dan klor-a menunjukan korelasi yang tinggi $(-0,89)$.

Upwelling terjadi sebagai akibat naiknya massa air dari kedalaman menuju permukaan yang membawa nutrien dan suhu yang lebih dingin. Anomali subsurface temperature sebagai respon terhadap upwelling terdeteksi jelas pada kedalaman $200 \mathrm{~m}$ hingga permukaan. Pada periode tertentu downwelling mencapai kedalaman hingga lebih dari $400 \mathrm{~m}$.

ENSO mempengaruhi intensitas upwelling. Pada saat terjadi el nino maka upwelling mengalami peningkatan intensitas yang membawa massa air dingin dan nutrien ke permukaan sehingga SPL di selatan Jawa mengalami penurunan $\left(-3^{\circ} \mathrm{C}\right)$, sedangkan konsentrasi klor-a mengalami peningkatan $\left(1 \mathrm{mg} / \mathrm{m}^{3}\right)$. Sebaliknya 
pada saat terjadi la nina maka intensitas upwelling mengalami pelemahan yang diikuti oleh peningkatan SPL $\left(2^{\circ} \mathrm{C}\right)$ dan penurunan konsentrasi klor-a $(-0,2 \mathrm{mg} /$ $\mathrm{m}^{3}$ ). Korelasi antara ENSO dengan SPL adalah sebesar $-0,78$, sedangkan korelasi antara ENSO dengan klor-a sebesar 0,76 .

Intensitas upwelling juga dipengaruhi oleh IOD. Pada saat terjadi IOD positif intensitas upwelling mengalami peningkatan yang diikuti oleh turunnya SPL $\left(-4,2^{\circ} \mathrm{C}\right)$ dan naiknya konsentrasi klor-a $(1,1$ $\mathrm{mg} / \mathrm{m}^{3}$ ), sebaliknya pada saat IOD negatif intensitas upwelling mengalami pelemahan yang diikuti oleh naiknya SPL $\left(2,6^{\circ} \mathrm{C}\right)$ dan turunnya konsentrasi klor-a $\left(-0,2 \mathrm{mg} / \mathrm{m}^{3}\right)$. Korelasi antara IOD dengan SPL adalah sebasar $-0,88$, sedangkan korelasi antara IOD dengan klor-a sebesar 0,81 .

\section{DAFTAR PUSTAKA}

Aldrian, E. \& Dwi Susanto, R. (2003). Identification of three dominant rainfall regions within Indonesia and their relationship to sea surface temperature. International Journal of Climatology, 23(12), pp.1435-1452.

Amri, K., Suman, A., Irianto, H.E. \& Wudianto, W. (2015). Effects Of Dipole Mode And El-Nino Events On Catches Of Yellowfin Tuna (Thunnus Albacares) In The Eastern Indian Ocean Off West Java. Indonesian Fisheries Research Journal, 21(2), Pp.75-90.

Barnes, W.L., Xiong, X. \& Salomonson, V.V. (2003). Status of terra MODIS and aqua MODIS. Advances in Space Research, 32(11), pp.2099-2106.

Brown, O.B., Minnett, P.J., Evans, R., Kearns, E., Kilpatrick, K., Kumar, A., Sikorski, R. \& Závody, A. (1999). MODIS infrared sea surface temperature algorithm algorithm theoretical basis document version 2.0. University of Miami, 31, pp.098-33.

Donlon, C.J., Minnett, P.J., Gentemann, C., Nightingale, T.J., Barton, I.J., Ward, B. \& Murray, M.J. (2002). Toward improved validation of satellite sea surface skin temperature measurements for climate research. Journal of Climate, 15(4), pp.353-369.

Du, Y., Qu, T. \& Meyers, G. (2008). Interannual variability of sea surface temperature off Java and Sumatra in a global GCM. Journal of Climate, 21(11), pp.24512465.

Gaillard, F., Autret, E., Thierry, V., Galaup, P., Coatanoan, C. \& Loubrieu, T. (2009). Quality control of large Argo datasets. Journal of Atmospheric and Oceanic Technology, 26(2), pp.337-351.

Gaol, J.L., Mahapatra, K., Okada, Y., Pasaribu, B.P., Manurung, D. \& Nurjaya, I.W. (2002). Fish Catch Relative to Environmental Parameters Observed from Satellite During ENSO and Dipole Mode Events 1997/98 In South Java Sea. Proceedings of PORSEC, pp.411-417.
Gould, W.J. (2005). From swallow floats to Argo-The development of neutrally buoyant floats. Deep Sea Research Part II: Topical Studies in Oceanography, 52(3), pp.529-543.

Gould, J., Roemmich, D., Wijffels, S., Freeland, H., Ignaszewsky, M., Jianping, X., Pouliquen, S., Desaubies, Y., Send, U., Radhakrishnan, K. \& Takeuchi, K. (2004). Argo profiling floats bring new era of in situ ocean observations. Eos, Transactions American Geophysical Union, 85(19), pp.185-191.

Horii, T., Ueki, I., Syamsudin, F., Sofian, I. \& Ando, K. (2016). Intraseasonal coastal upwelling signal along the southern coast of Java observed using Indonesian tidal station data. Journal of Geophysical Research: Oceans, 121(4), pp.2690-2708.

Hu, C., Lee, Z. \& Franz, B. (2012). Chlorophyll aalgorithms for oligotrophic oceans: A novel approach based on three-band reflectance difference. Journal of Geophysical Research: Oceans, 117(C1).

Ilahude, A.G. \& Nontji, A. (1999). Oseanografi Indonesia dan perubahan iklim global (El Nino dan La Nina). Puslitbang Oseanologi-LIPI Jakarta. Hlm, pp.1-13.

Iskandar 1, I., Rao 2, S.A. \& Tozuka, T. (2009). Chlorophyll-a bloom along the southern coasts of Java and Sumatra during 2006. International Journal of Remote Sensing, 30(3), pp.663-671.

Kunarso, K., Hadi, S., Ningsih, N.S. \& Baskoro, M.S. (2012). Variabilitas suhu dan klorofil-a di daerah upwelling pada variasi kejadian ENSO dan IOD di perairan selatan Jawa sampai Timor. Ilmu Kelautan: Indonesian Journal of Marine Sciences, 16(3), pp.171-180.

Kunarso, K., Hadi, S. \& Ningsih, N.S. (2005). Kajian lokasi upwelling untuk penentuan fishing ground potensial ikan tuna. Ilmu Kelautan: Indonesian Journal of Marine Sciences, 10(2), pp.61-67.

Kuswardani, R.T.D. \& Qiao, F. (2014). Influence of the Indonesian Throughflow on the upwelling off the east coast of South Java. Chinese science bulletin, 59(33), pp.4516-4523.

Meyers, G., McIntosh, P., Pigot, L. \& Pook, M. (2007). The years of El Niño, La Niña, and interactions with the tropical Indian Ocean. Journal of Climate, 20(13), pp.2872-2880.

Ningsih, N.S., Rakhmaputeri, N. \& Harto, A.B. (2013). Upwelling variability along the southern coast of Bali and in Nusa Tenggara waters. Ocean Science Journal, 48(1), pp.49-57.

O'Reilly, J.E., Maritorena, S., Mitchell, B.G., Siegel, D.A., Carder, K.L., Garver, S.A., Kahru, M. \& McClain, C., 1998. Ocean color chlorophyll algorithms for SeaWiFS. Journal of Geophysical Research: Oceans, 103(C11), pp.24937-24953.

Pranowo, W.S., A.R.T.D. Kuswardani, B. Nugraha, D. Novianto, U. Muawanah, H. Prihatno, W. Yu. (2016). Ocean-Climate Interaction of South Eastern Indian Ocean for Tuna Fisheries \& Its Socio-Economy Impacts. International Journal of Science \& Research 
5(4): 1956-1961.

Pranowo, W.S., Phillips, H. \& Wijffels, S. (2005). Upwelling Event 2003 Along South Java Sea and Lesser Sunda Islands. J. Segara, 1(2), pp.63-67.

Pranowo, W.S., B. Hendrajana, S. Burhanuddin. \& A. Supangat. (2003). Akuisisi Data Temperatur dan Salinitas Di Samudera Hindia dengan Menggunakan Argo Floats. Prosiding Seminar "Oseanografi untuk Pembangunan Sumberdaya Laut Berkelanjutan”. Pusat Riset Teknologi Kelautan. Badan Riset Kelautan dan Perikanan. hlm: 4-1 - 4-9.

Qu, T., Du, Y., Strachan, J., Meyers, G. \& Slingo, J. (2005). Sea Surface Temperature and Its Variability. Oceanography, 18(4), p.50.

Rahul, C. R. P. \& Salvekar, P.S. (2008). Phytoplankton blooms induced/sustained by cyclonic eddies during the Indian Ocean Dipole event of 1997 along the southern coasts of Java and Sumatra. Biogeosciences Discussions, 5(5), pp.3905-3918.

Savtchenko, A., Ouzounov, D., Ahmad, S., Acker, J., Leptoukh, G., Koziana, J. \& Nickless, D. (2004). Terra and Aqua MODIS products available from NASA GES DAAC. Advances in Space Research, 34(4), pp.710-714.

Silverman, S.G. (2003). Correlation and Simple Linear Regression. Radiology, 227, pp.617-628.

Siswanto \& Suratno. (2008). Seasonal Pattern of Wind Induced Upwelling over Java-Bali Sea Waters and Surrounding Area. International Journal of Remote Sensing and Earth Sciences (IJReSES), 5.

Sprintall, J., Chong, J., Syamsudin, F., Morawitz, W., Hautala, S., Bray, N. \& Wijffels, S. (1999). Dynamics of the South Java Current in the. Geophysical Research Letters, 26(16), pp.2493-2496.

Stramska, M. \& Stramski, D. (2005). Effects of a nonuniform vertical profile of chlorophyll concentration on remote-sensing reflectance of the ocean.

Susanto, R. \& Marra, J. (2005). Chlorophyll a Variability. Oceanography, 18(4), p.124.

Susanto, R.D., Gordon, A.L. \& Zheng, Q. (2001). Upwelling along the coasts of Java and Sumatra and its relation to ENSO. Geophysical Research Letters, 28(8), pp.1599-1602.

Wardani, R., W.S. Pranowo. \& E. Indrayanti. (2014). Variabilitas Salinitas Berkaitan dengan ENSO dan IOD di Samudera Hindia (Selatan Jawa hingga Selatan Nusa Tenggara) Periode Tahun 2004-2010. J. Harpodon 7(1): 9-18.

Valsala, V. \& Maksyutov, S. (2011). A short surface pathway of the subsurface Indonesian throughflow water from the Java coast associated with upwelling, Ekman transport, and subduction. International Journal of Oceanography, 2010.

Varela, R., Santos, F., Gómez-Gesteira, M., Álvarez, I., Costoya, X. \& Días, J.M. (2016). Influence of Coastal Upwelling on SST Trends along the South Coast of Java. PloS one, 11(9), p.e0162122.

Xing, W., Liao, X., Zhan, H. \& Liu, H. (2012). Estimates of potential new production in the Java-Sumatra upwelling system. Chinese journal of oceanology and limnology, 30(6), pp.1063-1067. 